\title{
The distribution and flow characteristics of surge-type glaciers in the Canadian High Arctic
}

\author{
Luke COPLAND, ${ }^{1}$ Martin J. SHaRP, Julian A. DOWDESWELL ${ }^{2}$ \\ ${ }^{1}$ Department of Earth and Atmospheric Sciences, University of Alberta, Edmonton, Alberta T6G 2E3, Canada \\ E-mail:martin.sharp@ualberta.ca \\ ${ }^{2}$ Scott Polar Research Institute and Department of Geography, University of Cambridge, Cambridge CB2 1ER, England
}

\begin{abstract}
A systematic review of 1959/60 aerial photography, and 1999/2000 Landsat 7 imagery, has identified 51 surge-type polythermal glaciers in the Canadian High Arctic. These were identified from the presence of features such as looped medial moraines, intense folding visible at the surface, rapid terminus advance, heavy surface crevassing, and high surface velocities. These observations suggest that surging glaciers are much more common than previously believed in the Canadian High Arctic, where only six surge-type glaciers have previously been described. Of the 51 surge-type glaciers identified in this study, 15 were observed in the active phase in the 1959/60 and/or 1999/2000 imagery. The most dramatic advances have occurred on western Axel Heiberg Island, where Iceberg, "Good Friday Bay" and Airdrop Glaciers have all advanced by 4-7 km between 1959 and 1999. For glaciers with repeat Landsat 7 coverage from 1999 and 2000, image correlation software was used to determine the magnitude and spatial distribution of surge velocities. For example, "Mittie" Glacier on Manson Icefield was moving at a rate of up to $1 \mathrm{~km} \mathrm{a}^{-1}$ over a distance of at least $25 \mathrm{~km}$ back from its terminus. The terminus of this glacier has advanced by at least $4 \mathrm{~km}$ since 1959, and the glacier was observed to be heavily crevassed during overflights in April 2000 , with clear signs of surface lowering of 10-25 m indicated by a strandline.
\end{abstract}

\section{INTRODUGTION}

Surge-type glaciers undergo cyclical non-steady flow (e.g. Meier and Post, 1969; Raymond, 1987). A relatively short active phase (a few months to a few years), during which glacier velocity increases by at least an order of magnitude and advance of the glacier terminus usually takes place, punctuates much longer intervals of stagnation (tens to a few hundreds of years), during which the lower portion of the glacier thins and mass builds up in an upper, reservoir area. A further surge transfers this mass down-glacier once more. The geographical distribution of surge-type glaciers appears to be non-random (Post, 1969). In the $36600 \mathrm{~km}^{2}$ of ice-covered area in Svalbard, for example, at least 132 glaciers representing $\sim 50 \%$ of the total glaciated area have been classified as surge-type (Hagen and others, 1993; Jiskoot and others, 2000). However, in the more easterly Russian islands of Franz Josef Land, Severnaya Zemlya and Novaya Zemlya, with $55600 \mathrm{~km}^{2}$ of ice, very few glaciers appear to have undergone surge activity (Dowdeswell and Williams, 1997).

The Canadian High Arctic islands, also known as the Queen Elizabeth Islands (QEI), contain almost $110000 \mathrm{~km}^{2}$ of polythermal glaciers and ice caps (Koerner, 1989) (Fig. 1). This is about $40 \%$ of the total area of Arctic ice outside Greenland (Dowdeswell, 1995), and 5\% of the Northern Hemisphere's ice cover (Koerner, 1989). Ice covers $80500 \mathrm{~km}^{2}$ on Ellesmere Island, about $16200 \mathrm{~km}^{2}$ on Devon Island, and $11700 \mathrm{~km}^{2}$ on Axel Heiberg Island (Fig. 1). Despite the large number of outlet and valley glaciers on these islands, very few have been observed to surge (Hattersley-Smith, 1964, 1969; Müller, 1969; Ommanney,
1969). However, no systematic study of these ice masses has been undertaken to investigate present and past surge activity.

The aim of this paper is to assess the extent of surge behaviour of glaciers of the Canadian High Arctic islands. Recent field observations of glaciers in the active phase of the surge cycle are combined with earlier reports of surge activity, and supplemented by a systematic search of imagery of the ice masses on Ellesmere, Devon and Axel Heiberg Islands for indications of surge activity.

\section{METHODS}

Digital satellite imagery from the Landsat 7 Enhanced Thematic Mapper Plus (ETM+) was used as the basis for a systematic search for criteria indicative of surges (Table 1). Summer imagery of the ice masses was acquired, because icesurface features diagnostic of glacier surging are most clearly recognized on bare glacier ice. These features can be recognized readily on Landsat 7 imagery, which has a spatial resolution in panchromatic mode of $15 \mathrm{~m}$ (e.g. Bindschadler and others, 2001). The available imagery covers all glacierized areas of the QEI up to the northern limit of data acquisition at $\sim 81.5^{\circ} \mathrm{N}$. An additional Landsat 4 image of southern Axel Heiberg Island from 1992 was used to further investigate the surging glaciers present in this area.

The 1959/60 aerial photography database, consisting of $\sim 10000$ images, was produced by scanning all available 1:60000 scale vertical aerial photographs of Devon, Ellesmere and Axel Heiberg Islands. The majority of these photographs originated from the Canadian Glacier Inventory at the National Water Resources Institute in Saskatoon, 


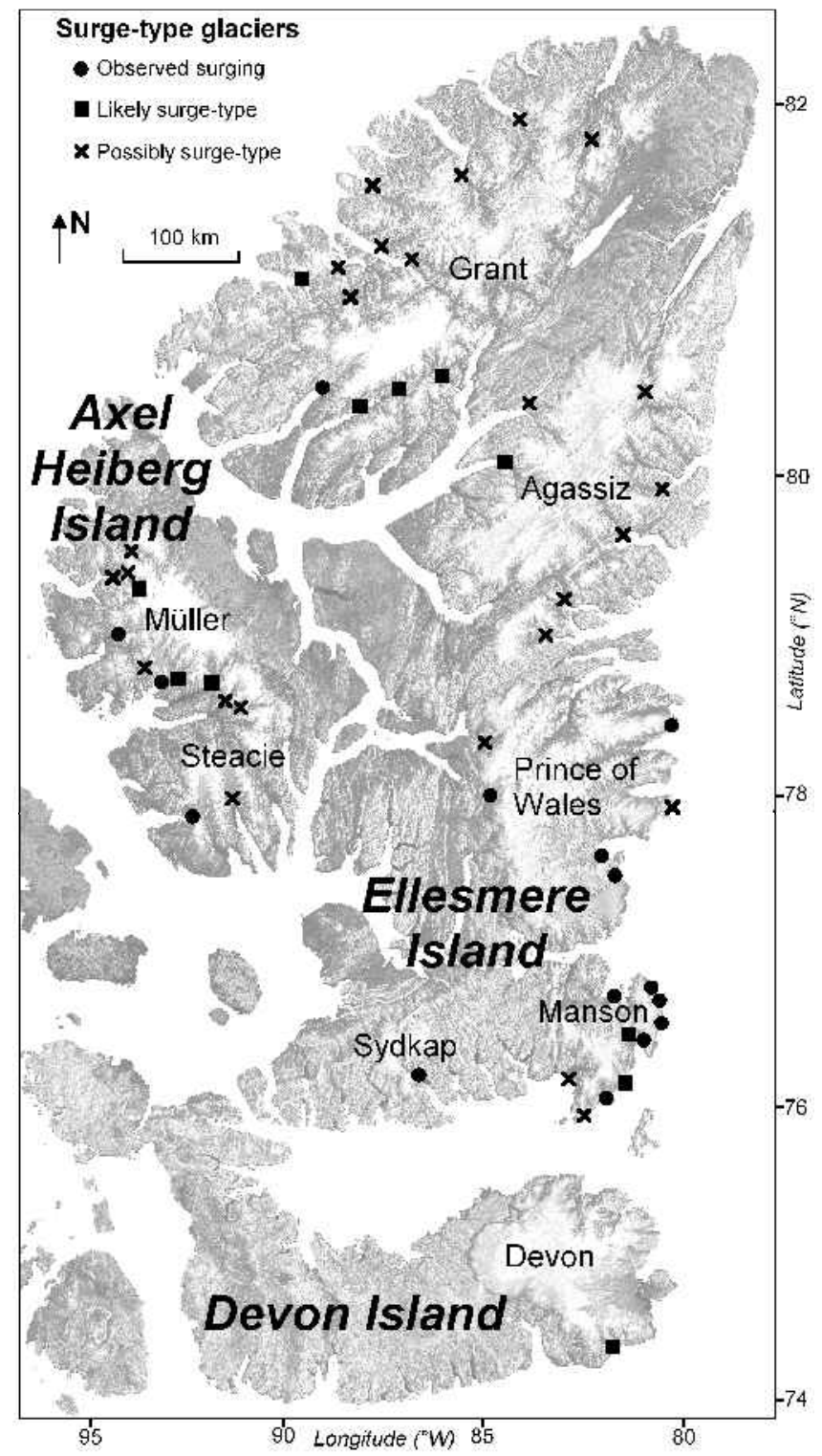

Fig. 1. Distribution of surge-type glaciers in the QEI identified in this study (base imagery from the RADARSAT Orthomosaic of Canada courtesy of the Canadian Centre for Remote Sensing). Icefield and ice-cap names are shown.

Saskatchewan, Canada. These stereo photographs were originally taken by the Royal Canadian Air Force for the production of the first detailed maps of the Canadian High Arctic islands. Each grey-scale photo covers an area of approximately $10 \times 10 \mathrm{~km}$, and was scanned at $300 \mathrm{dpi}$ resolution. Comparison was made between the aerial photography and Landsat 7 imagery for every glacier outlet and icemarginal area in the region of interest. The only exception was northernmost Ellesmere Island beyond the coverage of Landsat 7 (approximately 5\% of Grant Ice Cap), for which only the aerial photography was analyzed.

A number of features are regarded as indicators of whether or not glaciers and larger ice masses have surged during the residence time of the ice within a given drainage basin (Meier and Post, 1969; Sturm, 1987; Williams and others, 1991; Hambrey and Dowdeswell, 1994). These include: (a) looped moraines, formed as fast-flowing, active-phase surge-type glaciers flow past less active or stagnant neighbours, and deform the medial moraines between them; (b) ice structures, and in particular foliation, deformed in a
Table 1. Details of the Landsat imagery used in this study ( see Fig. 1 for icefield and ice-cap locations)

Sensor Path/row Date Time Location/icecap/icefield

GMT

Landsat 4 053/003 18 Jul. $1992 \quad$ N/A Steacie/southern Müller

Landsat 7 038/005 13 Jul. 1999 17:50:01 Manson

Landsat 7 038/006 13 Jul. 1999 17:50:25 Devon

Landsat 7 038/007 13 Jul. 1999 17:50:49 Devon

Landsat 7 041/247 $\quad$ 18 Jul. 1999 19:45:01 Northeastern Prince of Wales

Landsat $7 \quad 042 / 004 \quad 9$ Jul. $1999 \quad$ 18:14:19 Prince of Wales

Landsat 7 044/003 7 Jul. 1999 18:26:16 Prince of Wales

Landsat 7 044/004 7 Jul. 1999 18:26:40 Western Prince of Wales

Landsat 7 044/005 7 Jul. 1999 18:27:04 Sydkap

Landsat 7 044/006 7 Jul. 1999 18:27:28 Northwestern Devon/southwestern Ellesmere Islands

$\begin{array}{llll}\text { Landsat } 7 & \text { 049/001 } & 10 \text { Jul. } 1999 & \text { 18:56:23 Northern Agassiz }\end{array}$

Landsat 7 049/002 10 Jul. 1999 18:56:47 Southern Agassiz

Landsat 7 051/246 24 Jul. 1999 20:46:29 Eastern Grant

Landsat 7 051/247 24 Jul. 1999 20:46:51 Grant

Landsat 7 051/248 24 Jul. 1999 20:47:16 Western Grant/northern Müller

Landsat 7 053/003 22 Jul. 1999 19:21:55 Steacie

Landsat 7 059/001 $\quad 16$ Jul. 1999 19:58:12 Western Grant

Landsat 7 060/002 23 Jul. 1999 20:04:48 Müller

Landsat 7 062/246 21 Jul. 1999 21:54:26 Northwestern Grant

Landsat 7 036/006 2 Aug. 2000 17:36:25 Northeastern Devon/ southeastern Manson

Landsat 7 036/007 2 Aug. 2000 17:36:49 Southern Devon

Landsat 7 040/004 27 Jun. 2000 18:00:52 Eastern Prince of Wales

Landsat 7 040/005 27 Jun. 2000 18:01:16 Southern Prince of Wales

Landsat 7 040/006 $29 \mathrm{Jul} .2000 \quad$ 18:01:10 Western Devon

Landsat 7 047/003 28 Jun. 2000 18:43:43 Western Prince of Wales

similar fashion to looped moraines; (c) a heavily crevassed surface, indicative of a glacier in the active phase of the surge cycle; (d) potholes on the glacier surface during the quiescent phase; (e) a rapid advance of a glacier terminus when surrounding glaciers are relatively stable in ice-margin position; (f) shear margins on the glacier surface, formed at the boundary between fast-moving surging ice and slower nonsurging ice; $(\mathrm{g})$ surface velocities which are typically an order of magnitude or so higher than during the quiescent phase; (h) a strandline of ice on surrounding bedrock, formed when the glacier surface rapidly falls in elevation as a surge removes ice from the basin; and (i) a highly digitate tidewater terminus (i.e. a terminus which is markedly splayed by longitudinal crevasses) for actively surging glaciers that flow into the ocean.

Most of these features can occur on non-surge-type glaciers, but the presence of many of the features together is suggestive of surge behaviour. Marked velocity changes, heavy crevassing and rapid terminus retreat can also occur on glaciers during the tidewater glacier cycle (Meier and Post, 1987), when they are not related to surging. Consequently, on tidewater glaciers in our study area, we used additional evidence such as rapid terminus advance, looped surface moraines, deformed ice structures, potholes and strandlines to define a glacier as surge-type.

Each satellite image and the corresponding aerial photographs were examined systematically, in segments of up to approximately $100 \mathrm{~km}^{2}$, for the presence of surge features. This search was supplemented by direct visual observations of the glaciers and ice caps over much of Ellesmere and Devon Islands, made during $>45$ hours of flying, representing about $6000 \mathrm{~km}$ of flight tracks. This work was undertaken 
Table 2. List of surge-type glaciers in the QEI (* indicates unofficial name)

\begin{tabular}{|c|c|c|c|c|c|}
\hline $\begin{array}{l}\text { Glacier name } \\
\quad \text { /Inventory №. }\end{array}$ & Index & $\begin{array}{c}\text { Ice-cap/icefield } \\
\text { name }\end{array}$ & Location & Aerial photo & Comments and surge features \\
\hline
\end{tabular}

\begin{tabular}{l}
\hline Mittie* \\
$46421 F-19$ \\
Clarence Head South* \\
$46421 \mathrm{G}-66$ \\
Clarence Head North* \\
$46421 \mathrm{G}-85$ \\
Mount Glenworth* \\
$46421 \mathrm{G}-91$ \\
Cape Norton Shaw* \\
$46421 \mathrm{G}-46$ \\
Unnamed \\
$46421 \mathrm{G}-9$ \\
Cape Tennyson* \\
$46421 \mathrm{H}-38$ \\
Cory \\
$46421 \mathrm{H}-25$ \\
Wilcox \\
$46421 \mathrm{H}-2$ \\
Jakeman \\
$46421 \mathrm{~A}-75$ \\
Jolliffe (north arm)
\end{tabular}

Benedict

Parrish

Dobbin Bay*

John Richardson Bay South*

Lake Tuborg*

d'Iberville

Taggart Lake*

Alfred Newton

Kooetigeto River*

Cape Dunsterville*

Wykeham Glacier South*

Easter Island South*

Sydkap

46422C-154

Cunningham West 46460I-22

Barrier

Chapman

Disraeli

M'Clintock

Milne

East Yelverton Inlet*

Kulutingwak Fiord*

South Yelverton Inlet*

North Phillips Inlet*

Otto
1 Northern $\quad 76^{\circ} 50^{\prime} \mathrm{N}$ Manson $\quad 79^{\circ} 10^{\prime} \mathrm{W}$ 1 Eastern $\quad 76^{\circ} 40^{\prime} \mathrm{N}$ Manson $\quad 77^{\circ} 55^{\prime} \mathrm{W}$ 1 Eastern $\quad 76^{\circ} 49^{\prime} \mathrm{N}$, Manson $\quad 77^{\circ} 50^{\prime} \mathrm{W}$ 1 Northeastern $76^{\circ} 53^{\prime} \mathrm{N}$ Manson $\quad 77^{\circ} 55^{\prime} \mathrm{W}$ 1 Southern $76^{\circ} 34^{\prime} \mathrm{N}$ Manson $\quad 78^{\circ} 38^{\prime} \mathrm{W}$

2 Southern $76^{\circ} 36^{\prime} \mathrm{N}$, Manson $\quad 78^{\circ} 52^{\prime} \mathrm{W}$

2 Southern $\quad 76^{\circ} 19^{\prime} \mathrm{N}$ Manson $\quad 79^{\circ} 22^{\prime} \mathrm{W}$

1 Southern $\quad 76^{\circ} 16^{\prime} \mathrm{N}$ Manson $\quad 79^{\circ} 59^{\prime} \mathrm{W}$

3 Southwestern $76^{\circ} 11^{\prime} \mathrm{N}$, Manson $\quad 80^{\circ} 45^{\prime} \mathrm{W}$

3 Southwestern $76^{\circ} 28^{\prime} \mathrm{N}$, Manson $\quad 80^{\circ} 45^{\prime} \mathrm{W}$

3 Northeastern $80^{\circ} 41^{\prime} \mathrm{N}$, Agassiz $\quad 71^{\circ} 45^{\prime} \mathrm{W}$

3 Southern $\quad 79^{\circ} 22^{\prime} \mathrm{N}$, Agassiz $\quad 78^{\circ} 15^{\prime} \mathrm{W}$

3 Southern $\quad 79^{\circ} 34^{\prime} \mathrm{N}$ Agassiz $\quad 77^{\circ} 13^{\prime} \mathrm{W}$

3 Eastern $\quad 79^{\circ} 55^{\prime} \mathrm{N}$ Agassiz $\quad 74^{\circ} 20^{\prime} \mathrm{W}$ $80^{\circ} 04^{\prime} \mathrm{N}$, $\begin{array}{ll}\text { Agassiz } & 72^{\circ} 30^{\prime} \mathrm{W} \\ \text { Northwestern } & 80^{\circ} 54^{\prime} \mathrm{N},\end{array}$ $\begin{array}{ll}\text { Northwestern } & 80^{\circ} 54^{\prime} \mathrm{N}, \\ \text { Agassiz } & 76^{\circ} 20^{\prime} \mathrm{W}\end{array}$

2 Western Agas- $80^{\circ} 33^{\prime} \mathrm{N}$ siz $\quad 77^{\circ} 50^{\prime} \mathrm{W}$

1 Western POW $78^{\circ} 26^{\prime} \mathrm{N}$, $81^{\circ} 26^{\prime} \mathrm{W}$ $78^{\circ} 34^{\prime} \mathrm{N}$, $\begin{array}{ll}\text { POW } & 74^{\circ} 55^{\prime} \mathrm{W} \\ \text { Northwestern } & 78^{\circ} 47^{\prime} \mathrm{N},\end{array}$ $\begin{array}{ll}\text { Northwestern } & 78^{\circ} 47^{\prime} \mathrm{N} \\ \text { POW } & 81^{\circ} 12^{\prime} \mathrm{W}\end{array}$ 3 Eastern POW $78^{\circ} 03^{\prime} \mathrm{N}$ $75^{\circ} 42^{\prime} \mathrm{W}$ $77^{\circ} 50^{\prime} \mathrm{N}$, $78^{\circ} 18^{\prime} \mathrm{W}$ $77^{\circ} 43^{\prime} \mathrm{N}$, $78^{\circ} 10^{\prime} \mathrm{W}$ $76^{\circ} 39^{\prime} \mathrm{N}$ $85^{\circ} 10^{\prime} \mathrm{W}$ $74^{\circ} 34^{\prime} \mathrm{N}$, $\begin{array}{lll} & \text { Devon } & 81^{\circ} 25^{\prime} \mathrm{W} \\ & \text { Eastern Grant } & 82^{\circ} 24^{\prime} \mathrm{N},\end{array}$ $69^{\circ} 35^{\prime} \mathrm{W}$ $81^{\circ} 14^{\prime} \mathrm{N}$, $79^{\circ} 45^{\prime} \mathrm{W}$ $82^{\circ} 40^{\prime} \mathrm{N}$, $72^{\circ} 30^{\prime} \mathrm{W}$ $82^{\circ} 26^{\prime} \mathrm{N}$, $76^{\circ} 10^{\prime} \mathrm{W}$ $82^{\circ} 30^{\prime} \mathrm{N}$, $80^{\circ} 40^{\prime} \mathrm{W}$ $82^{\circ} 08^{\prime} \mathrm{N}$, $80^{\circ} 45^{\prime} \mathrm{W}$ $82^{\circ} 03^{\prime} \mathrm{N}$ $83^{\circ} 12^{\prime} \mathrm{W}$ $82^{\circ} 01^{\prime} \mathrm{N}$, $79^{\circ} 40^{\prime} \mathrm{W}$ $82^{\circ} 02^{\prime} \mathrm{N}$, $84^{\circ} 56^{\prime} \mathrm{W}$ $81^{\circ} 18^{\prime} \mathrm{N}$, $84^{\circ} 35^{\prime} \mathrm{W}$
A16682-036 S

Surging in 1999, peak velocities $>1 \mathrm{~km} \mathrm{a}^{-1}$, terminus advance $>4 \mathrm{~km}$ 1959-99

A16613-141 Surging in 1999, peak velocities $>400 \mathrm{~m} \mathrm{a}^{-1}$, looped moraines, distinct shear margins

A16613-137 Recently or currently surged in 1999, looped moraines, shear margins, terminus advanced $\sim 0.5 \mathrm{~km} 1959-99$

A16613-136 Surging in 1999, peak velocities $\sim 250 \mathrm{~m} \mathrm{a}^{-1}$, shear margins, terminus advanced $\sim 0.5 \mathrm{~km} 1959-99$

A16679-023 Surging in 1959, looped moraines and folds, $\sim 2 \mathrm{~km}$ retreat 1959-99, terminus heavily crevassed in 1959

A16733-011 Many looped moraines along glacier edges in both 1959 and 1999 suggestive of surging and shear margins

A16682-023 Extensive surface folding and looping over terminus in 1959 and 1999, some shear margins

A16682-170 Recently or currently surged in 1959, with heavy crevassing (none in

A16787-116 1999), shear margins, looped moraines

A16682-178 Terminus 0.5 km more advanced in 1959 than 1999, some cross-cutting crevasses, some folding

A16781-010 Suggestion of surging from looped folds/moraines close to terminus

A16682-185

A16604-031 Looped ice banding in 1959 and 1999 that is difficult to explain with current flow regime

A16779-073 Extensive looping and folding of moraines/ice bands over the terminus in A16694-192 1959 and 1999

A16794-012 Folding and shearing of surface moraines/ice bands over terminus in 1959 A16721-085 and 1999

A16616-053/054 Heavy terminus crevassing in 1959 (little in 1999), a few small looped moraines and shear margins

A16607-042/179 A few looped moraines in 1959 and 1999, possible shear margin close to terminus

A16694-041 Heavily crevassed terminus (more in 1999 than 1959), highly digitate tidewater terminus in 1959 and 1999

A16691-032 Looped moraines on terminus in 1959 (none visible in 1999), distinct

A16792-036 shear margins, digitate tidewater terminus

Al6678-048 Surging in 1999 into a proglacial lake, advanced $\sim 3 \mathrm{~km} \mathrm{1959-99,}$

A16692-088 distinctive shear margin, extensive surface folding

A16607-009 Currently/recently surged (started 1982), heavy crevassing (none in

A16603-016 1959), shear margins, 0.75 km advance 1959-99

A16692-080 Large moraine loops in 1959 and 1999 which cannot be explained with current flow configuration

A16607-230 Heavily crevassed in 1959 (none in 1999), extensive downwasting 1959-99

A16726-038/039 Surging in 1959 with heavy crevassing, potholes across terminus in 1999 , $\sim 1 \mathrm{~km}$ retreat 1959-99

A16726-041 Surging in 1959 with heavy crevassing and over-running of surrounding

Al6679-048 glaciers, stagnant in 1999 with potholing

A16722-010/011 Currently or recently surged in 1959 with extensive surface folding/shearing, terminus retreat $\sim 9.5 \mathrm{~km} 1959-99$

A16787-034 Extensive surface folding in 1959 and 1999, retreat of eastern side by $\sim 2 \mathrm{~km}$ 1959-99

A16603-106 Surface folding adjacent to terminus in 1959 and 1999

A16693-174 Large and extensive folding of surface moraines in 1959 and 1999, impeded surface drainage

A16725-095/9 Some looped surface moraines in 1959 and 1999, with large number of potholes over floating terminus

Al6691-076/078 Some looped moraines/ice banding in 1959 and 1999, many potholes over floating terminus

A16728-014 Several looped moraines in 1959 and 1999, many potholes over floating A16785-082 terminus

A16785-091 Looped marginal moraines in 1959 and 1999, digitate tidewater terminus A16728-020 advanced $\sim 1 \mathrm{~km}$ 1959-99

A16785-192 Looped moraine close to terminus in 1959 and 1999

A16734-011

A16690-102 Large folded moraines over terminus in 1959 and 1999, as well as some

A16691-184 looping/folding higher in ablation area

A16724-076 Heavily crevassed terminus in 1959 and 1999, terminus highly digitate and advanced $\sim 0.75 \mathrm{~km} 1959-99$

Al6734-030 Surging in 1959 and 1999, 2 km advance 1959-99, heavy crevassing, not A16785-175 surging in 1950 (trimetrogon photo: T405L-70) 
Table 2. cont.

\begin{tabular}{|c|c|c|c|c|c|}
\hline $\begin{array}{l}\text { Glacier name } \\
\quad \text { /nventory No. }\end{array}$ & Index & $\begin{array}{l}\text { Ice-cap/icefield } \\
\text { name }\end{array}$ & Location & Aerial photo & Comments and surge features \\
\hline East Hare Fiord* & 2 & $\begin{array}{l}\text { Southwestern } \\
\text { Grant }\end{array}$ & $\begin{array}{l}81^{\circ} 13^{\prime} \mathrm{N} \\
81^{\circ} 30^{\prime} \mathrm{W}\end{array}$ & $\begin{array}{l}\text { A16788-139 } \\
\text { A16978-086 }\end{array}$ & $\begin{array}{l}\text { Extensive and large folding and looping of moraines/ice bands across } \\
\text { terminus in } 1959 \text { and } 1999\end{array}$ \\
\hline North Hare Fiord* & 2 & $\begin{array}{l}\text { Southwestern } \\
\text { Grant }\end{array}$ & $\begin{array}{l}81^{\circ} 08^{\prime} \mathrm{N} \\
83^{\circ} 18^{\prime} \mathrm{W}\end{array}$ & A16724-030 & $\begin{array}{l}\text { Large folding of moraine in } 1959 \text { and 1999, } \sim 1 \mathrm{~km} \text { retreat from tidewater } \\
\text { in } 1959 \text { to grounded in } 1999\end{array}$ \\
\hline Unnamed & 3 & $\begin{array}{l}\text { Western } \\
\text { Grant }\end{array}$ & $\begin{array}{l}81^{\circ} 52^{\prime} \mathrm{N} \\
82^{\circ} 50^{\prime} \mathrm{W}\end{array}$ & A16724-046 & $\begin{array}{l}\text { Concertina-like folding across terminus in } 1959 \text { and particularly } \\
\text { pronounced in } 1999\end{array}$ \\
\hline $\begin{array}{l}\text { Unnamed } \\
\quad 46444 \mathrm{H}-42\end{array}$ & 3 & $\begin{array}{l}\text { Northwestern } \\
\text { Müller }\end{array}$ & $\begin{array}{l}80^{\circ} 10^{\prime} \mathrm{N} \\
93^{\circ} 32^{\prime} \mathrm{W}\end{array}$ & A16755-044 & Some folding close to terminus in 1959 and 1999 \\
\hline $\begin{array}{l}\text { Unnamed } \\
\quad 46444 \mathrm{H}-63\end{array}$ & 3 & $\begin{array}{l}\text { Northwestern } \\
\text { Müller }\end{array}$ & $\begin{array}{l}80^{\circ} 10^{\prime} \mathrm{N} \\
93^{\circ} 42^{\prime} \mathrm{W}\end{array}$ & A16755-044 & Some folding close to terminus in 1959 (not visible in 1999) \\
\hline $\begin{array}{l}\text { Unnamed } \\
\quad 46444 \mathrm{H}-45\end{array}$ & 2 & $\begin{array}{l}\text { Northwestern } \\
\text { Müller }\end{array}$ & $\begin{array}{l}80^{\circ} 08^{\prime} \mathrm{N} \\
93^{\circ} 15^{\prime} \mathrm{W}\end{array}$ & A16861-056 & $\begin{array}{l}\text { Widespread folding across terminus in } 1959 \text { and 1999, } \sim 0.2 \mathrm{~km} \text { advance } \\
\text { 1959-99 }\end{array}$ \\
\hline $\begin{array}{l}\text { Unnamed } \\
\quad 46444 \mathrm{~J}-18\end{array}$ & 3 & $\begin{array}{l}\text { Northern } \\
\text { Müller }\end{array}$ & $\begin{array}{l}80^{\circ} 20^{\prime} \mathrm{N} \\
93^{\circ} 10^{\prime} \mathrm{W}\end{array}$ & A16753-133 & Folding across terminus (more pronounced in 1959 than 1999) \\
\hline $\begin{array}{l}\text { Airdrop* } \\
\quad 46444 \mathrm{G}-8\end{array}$ & 1 & $\begin{array}{l}\text { Western } \\
\text { Müller }\end{array}$ & $\begin{array}{l}79^{\circ} 50^{\prime} \mathrm{N} \\
93^{\circ} 40^{\prime} \mathrm{W}\end{array}$ & $\begin{array}{l}\text { A16755-052 } \\
\text { A16754-035 }\end{array}$ & $\begin{array}{l}\text { Surging in 1999, heavily crevassed, } \sim 4.5 \mathrm{~km} \text { advance 1959-99, extensive } \\
\text { surface folding and looping }\end{array}$ \\
\hline $\begin{array}{l}\text { Unnamed } \\
\quad 46442 \mathrm{~A}-42\end{array}$ & 3 & $\begin{array}{l}\text { Southwestern } \\
\text { Müller }\end{array}$ & $\begin{array}{l}79^{\circ} 32^{\prime} \mathrm{N} \\
93^{\circ} 18^{\prime} \mathrm{W}\end{array}$ & A16755-059 & Surface folding close to terminus in 1959 and 1999 \\
\hline $\begin{array}{l}\text { Iceberg } \\
\quad 46444 \mathrm{~F}-56\end{array}$ & 1 & $\begin{array}{l}\text { Southwestern } \\
\text { Müller }\end{array}$ & $\begin{array}{l}79^{\circ} 28^{\prime} \mathrm{N} \\
92^{\circ} 15^{\prime} \mathrm{W}\end{array}$ & $\begin{array}{c}\text { A16753-113 } \\
\text { A16754-105/107 }\end{array}$ & $\begin{array}{l}\text { Surging in } 1992 \text { and } 1999 \text { with heavy crevassing (potholed in 1959), large } \\
\text { looped moraines, } \sim 5 \mathrm{~km} \text { advance } 1959-99 \text {. Tributary Finsterwalder } \\
\text { Glacier may also be surging in } 1992 \text { and } 1999\end{array}$ \\
\hline $\begin{array}{l}\text { Sphinx* } \\
\quad 46444 \mathrm{~F}-65\end{array}$ & 2 & $\begin{array}{l}\text { Southwestern } \\
\text { Müller }\end{array}$ & $\begin{array}{l}79^{\circ} 29^{\prime} \mathrm{N} \\
91^{\circ} 45^{\prime} \mathrm{W}\end{array}$ & A16836-126 & $\begin{array}{l}\text { Folded moraines close to terminus in } 1959 \text { and 1999, partly fed by } \\
\text { tributary of surging Iceberg Glacier }\end{array}$ \\
\hline $\begin{array}{l}\text { Thompson } \\
\quad 46444 \mathrm{E}-21\end{array}$ & 2 & $\begin{array}{l}\text { Southern } \\
\text { Müller }\end{array}$ & $\begin{array}{l}79^{\circ} 26^{\prime} \mathrm{N} \\
90^{\circ} 30^{\prime} \mathrm{W}\end{array}$ & Al6864-033/036 & $\begin{array}{l}\text { Large looped and folded moraines across terminus in } 1959 \text { and } 1999, \\
\sim 0.75 \mathrm{~km} \text { advance } 1959-99\end{array}$ \\
\hline $\begin{array}{l}\text { Strand } \\
\quad 46444 \mathrm{D}-8\end{array}$ & 3 & $\begin{array}{l}\text { Northern } \\
\text { Steacie }\end{array}$ & $\begin{array}{l}79^{\circ} 18^{\prime} \mathrm{N} \\
90^{\circ} 02^{\prime} \mathrm{W}\end{array}$ & A16859-020 & Few looped moraines over terminus in 1959 and 1999 \\
\hline $\begin{array}{l}\text { Unnamed } \\
\quad 46444 \mathrm{D}-17\end{array}$ & 3 & $\begin{array}{l}\text { Northern } \\
\text { Steacie }\end{array}$ & $\begin{array}{l}79^{\circ} 16^{\prime} \mathrm{N} \\
89^{\circ} 34^{\prime} \mathrm{W}\end{array}$ & A16859-113 & Few looped moraines over terminus in 1959 and 1999 \\
\hline $\begin{array}{l}\text { Glacier Fiord* } \\
\text { 46441B-25 }\end{array}$ & 3 & $\begin{array}{l}\text { Southern } \\
\text { Steacie }\end{array}$ & $\begin{array}{l}78^{\circ} 38^{\prime} \mathrm{N} \\
90^{\circ} 05^{\prime} \mathrm{W}\end{array}$ & A16864-053 & Few looped moraines over terminus in 1959 and 1999 \\
\hline $\begin{array}{l}\text { Good Friday Bay* } \\
\quad 46441 \text { C-14 }\end{array}$ & 1 & $\begin{array}{l}\text { Southwestern } \\
\text { Steacie }\end{array}$ & $\begin{array}{l}78^{\circ} 33^{\prime} \mathrm{N} \\
91^{\circ} 30^{\prime} \mathrm{W}\end{array}$ & $\begin{array}{l}\text { A16754-083 } \\
\text { A16864-063 }\end{array}$ & $\begin{array}{l}\text { Surging in } 1992 \text { and 1999, } 7 \mathrm{~km} \text { advance 1959-99, looped surface } \\
\text { moraines, surge initiated 1952-59 (Müller, 1969) }\end{array}$ \\
\hline
\end{tabular}

Notes: Index: 1 = confirmed: active phase observed, many distinct surge features; 2 = likely: many surge features, active phase not observed; $3=$ possible: a few surge features, active phase not observed. POW, Prince of Wales Icefield. See Figure 1 for map of glacier, icefield and ice-cap locations. Inventory numbers from Ommanney (1989).

in April 2000, primarily to obtain radio-echo sounding data on ice thickness and surface and bed topography for another project. During the airborne programme, visual observations were made throughout, and the locations and descriptions of any ice-surface features indicative of possible surge activity were logged.
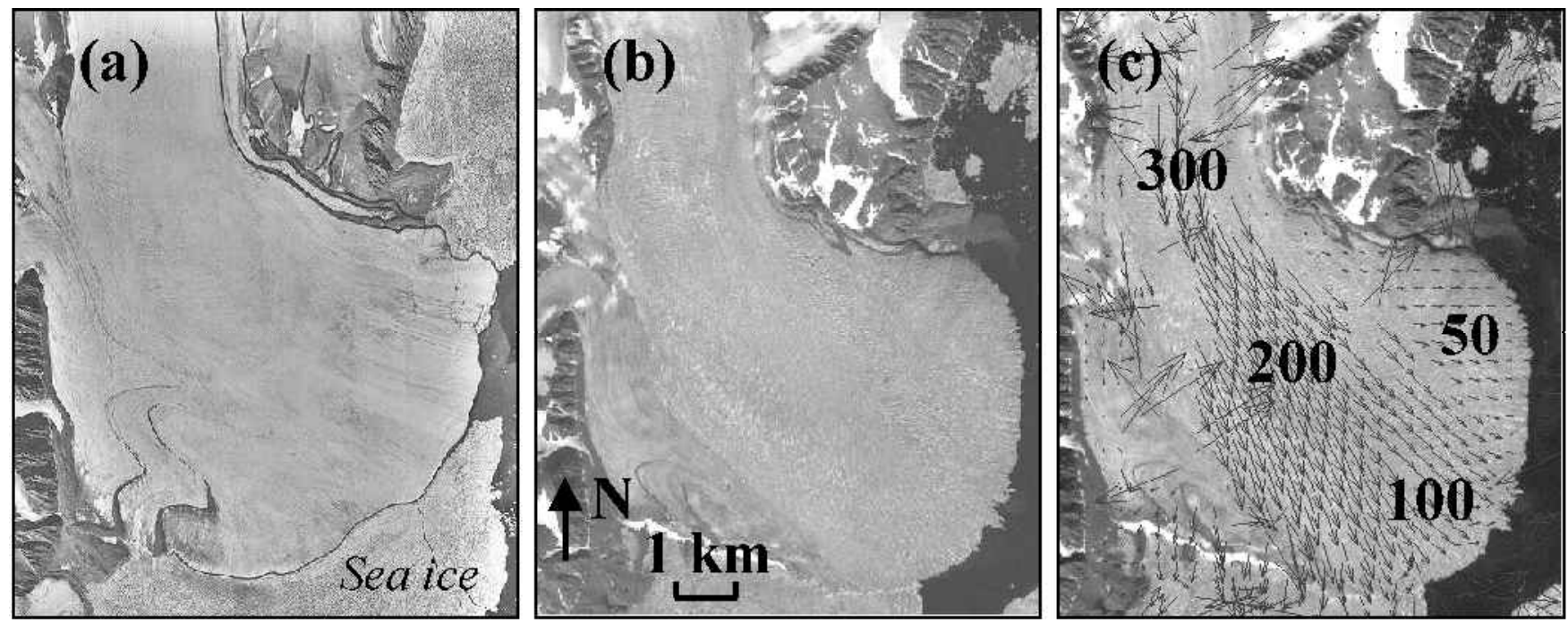

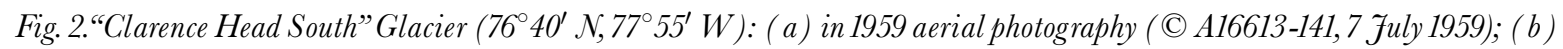
in 1999 Landsat 7 imagery (path 038, row 005, 13 July 1999); (c) surface parallel velocities ( $m a^{-5}$ ) determined from image correlation between 1999 and 2000 Landsat 7 imagery (path 038, row 005, 13 Fuly 1999; path 036, row 007, 2 August 2000). Large, localized vectors with anomalous flow directions indicate locations where the image correlation software did not correctly match the two images, and should be ignored. 
Where glaciers were thought to be surging, IMCORR software (Scambos and others, 1992) was used to determine ice velocities when repeat clear-sky Landsat 7 coverage was available for both 1999 and 2000. IMCORR takes two orthorectified images as input, and attempts to match small subscenes to determine displacements. The highest correlation index between subscenes within a specified search radius provides the best estimate of surface velocity and direction. Image correlation results are reported here only when velocity vectors displayed a consistent pattern across the glacier surface.

Few glaciers in the study area are named, so, to facilitate description, nearby features were often used to generate unofficial names. Table 2 indicates where such unofficial names have been used and in the text all unofficial names are initially identified by inverted commas. Official names were verified against the master record held by the Canadian Permanent Committee on Geographical Names website (http://geonames.nrcan.gc.ca). In Table 2, reference is also made to the inventory number (where available) for each glacier provided in the Glacier Atlas of Canada (Ommanney, 1989). Due to space limitations, most of this discussion focuses on glaciers that have been observed in the active phase of the surge cycle.

\section{RESULTS}

To provide an indication of the likelihood that a glacier is surge-type, we classified all glaciers in the QEI into one of four categories (similar to Hamilton, 1992):

1. Confirmed surging: active surge phase observed, many distinct surge features

2. Likely to have surged: many distinct surge features, but active phase not observed

3. Possible: a few surge features present, and active phase not observed

4. Non-surge: no surge features present.

Most glaciers from the Canadian High Arctic islands were of non-surge type, but 51 were identified as surge-type (Fig. 1; Table 2). Of these, 15 were observed in the active phase and classified as type $1 ; 11$ were classified as type 2 (likely surge-type); and 25 were classified as type 3 (possibly surge-type). This provides a conservative estimate of the number of surge-type glaciers in the Canadian High Arctic, as the surge features are not always easy to identify, and a glacier must have surged relatively recently to produce diagnostic remnant surge features. For example, glaciers which were actively surging in 1999/2000 often showed little evidence of surging in 1959/60 imagery.

\section{Manson Icefield}

The highest concentration of glaciers observed in the active phase of the surge cycle occurs around the north and east coast of Manson Icefield, southeast Ellesmere Island (Fig. 1; Table 2). This is one of the smaller icefields in the study area, and no surge-type glaciers have previously been described from this area.

"Mittie" Glacier, draining north from Manson Icefield, is the largest glacier observed to be actively surging in the QEI, with a drainage area of approximately $2000 \mathrm{~km}^{2}$. The glacier surface was relatively undisturbed and uncrevassed in 1959/60, but very heavily crevassed in 1999 and 2000. Observations by one of the authors (J.A.D.) during an overflight in April 2000 confirmed that the crevassing extended from the terminus into the accumulation basin about $30 \mathrm{~km}$ up-glacier. The tributary glaciers to the east and west were also crevassed, in many cases right to their headwalls. There is evidence of surface lowering of $10-25 \mathrm{~m}$ around $15-20 \mathrm{~km}$ from the margin, as indicated by a strandline. The glacier has advanced $>4 \mathrm{~km}$ northward into Smith Bay across a $9 \mathrm{~km}$ wide terminus relative to its position in 1959/60, and the inner part of Smith Bay contains large numbers of icebergs. The icebergs vary in shape from tabular to highly irregular, reach $>0.5 \mathrm{~km}$ in width, and are larger and more numerous than those seen from other non-surging tidewater glaciers in this region. Image correlation between Landsat 7 imagery from 7 July 1999 and 2 August 2000 indicates that maximum velocities reached $\sim 1 \mathrm{~km} \mathrm{a}^{-1}$ approximately $20 \mathrm{~km}$ up-glacier from the terminus, with velocities in most areas $>600 \mathrm{~m} \mathrm{a}^{-1}$.

Three actively surging glaciers along the eastern margin of Manson Icefield (from north to south: "Mount Glenworth", "Clarence Head North" and "Clarence Head South" all show similar changes since 1959/60. Their surfaces have changed from smooth to heavily crevassed, there are distinct shear margins between fast-moving ice in the glacier centre and non-surging ice towards the glacier edges in 1999/2000, their tidewater termini have advanced by $\sim 0.5 \mathrm{~km}$, and their termini are now markedly digitate (Fig. $2 \mathrm{a}$ and b). Image correlation indicates that peak velocities on Mount Glenworth Glacier were $>250 \mathrm{~m} \mathrm{a}^{-1}$ in 1999/2000. Good image-correlation results could not be obtained for Clarence Head North Glacier, which suggests either that the glacier surface is too broken up for comparison, or that the ice motion is too low for detection because the glacier has recently stopped surging. On Clarence Head South Glacier, a very clear pattern of surface velocities was determined by IMCORR, with distinct shear margins on either side of the main fast-moving ice body (Fig. 2c). Velocities near the equilibrium line reached a peak of almost $400 \mathrm{~m} \mathrm{a}^{-1}$, and gradually decreased to a velocity of $\sim 100 \mathrm{~m} \mathrm{a}^{-1}$ close to the terminus. For comparison, typical mean annual surface velocities on large valley glaciers in the Canadian High Arctic are 20-40 $\mathrm{ma}^{-1}$, although summer velocities on valley glaciers may reach twice these (Iken, 1974; Koerner, 1989; Copland, 2001).

Two other glaciers on Manson Icefield were observed in the active phase: "Cape Norton Shaw" and Cory Glaciers. Both of these were surging in 1959/60, when their respective termini were $\sim 2$ and $\sim 0.75 \mathrm{~km}$ more advanced than today. They currently appear to be in the quiescent phase, with relatively smooth and uncrevassed surfaces compared to heavily crevassed surfaces in 1959/60. Looped surface moraines and looped ice foliation are evident in both the aerial photography and Landsat imagery of these glaciers.

\section{Sydkap Ice Cap}

Only one glacier on Sydkap Ice Cap was identified as surgetype. Sydkap Glacier, flowing into South Cape Fiord, appears to have been surging in 1959/60, but its tidewater terminus has retreated $\sim 9.5 \mathrm{~km}$ since then. This is one of the largest retreats of any glacier reported in the Canadian High Arctic, and Koerner (1989) states that $\sim 6.5 \mathrm{~km}$ of retreat occurred between 1957 and 1974. This glacier has not previously been mentioned as surge-type, although extensive surface folding, shearing and crevassing are evident in the 
aerial photography. It is also possible that this retreat occurred as part of the tidewater glacier cycle, although the features such as surface folding and shearing suggest that surging is a more likely explanation.

\section{Prince of Wales Icefield}

Alfred Newton Glacier on the eastern side of Prince of Wales Icefield, and "Taggart Lake" Glacier on the western side of the icefield, are both currently surging but were not surging in 1959/60. W. Blake, Jr and E. Blake (personal communication, 2000) made observations of Alfred Newton Glacier from nearby Cape Herschel. The previously relatively unbroken surface of this glacier became crevassed and the glacier began to advance in summer 1982. The digitate tidewater terminus is currently advanced $\sim 0.75 \mathrm{~km}$ from its 1959 position. Landsat 7 imagery from summer 1999 shows that the entire glacier is still crevassed, especially high up in the accumulation area. No velocity measurements are available for the glacier, but the implication of these observations is that the glacier has remained active for at least 17 years.

Taggart Lake Glacier was observed to be surging by one of the authors (M.J.S.) during an overflight in May 1999, when a heavily crevassed surface, extensive surface looping and folding, and distinctive shear margins were apparent. The glacier terminus is currently advanced $\sim 3 \mathrm{~km}$ from its 1959/60 position, resulting in the almost complete filling of the large proglacial Taggart Lake that used to exist in front of the glacier. This glacier is somewhat unusual in comparison to the other surge glaciers identified in the QEI because its terminus is not well confined within a valley, but is rather a part of the broad western margin of Prince of Wales Icefield (Fig. 1).

In the southeast part of the icefield, two nearby glaciers ("Wykeham Glacier South" and "Easter Island South") were observed to be surging in the 1959/60 aerial photography, but were not surging in 1999. Both of these glaciers form part of a large ice lobe that dominates the southeast part of Prince of Wales Icefield, and are not well constrained by surrounding bedrock. They were heavily crevassed across their termini in the earlier imagery, compared to a markedly potholed surface in 1999. Easter Island South Glacier also over-ran an adjacent outlet ice lobe to the south in 1959/60 and prevented it reaching the ocean, whereas today the glacier has retreated by $\sim 1-2 \mathrm{~km}$ and the adjacent ice lobe is now able to reach the ocean.

\section{Grant Ice Cap}

Otto Glacier, which flows southwestwards from Grant Ice Cap, was reported to be surging by Hattersley-Smith (1964, 1969). The surge reportedly began between 1950 and 1959 when the lower $25 \mathrm{~km}$ of the glacier became highly crevassed, all traces of surface melt streams were obliterated and the previously grounded terminus over-rode stagnant marginal ice and entered tidewater as it advanced $\sim 3 \mathrm{~km}$ into Otto Fiord. By 1964 the glacier had advanced a further $2-3 \mathrm{~km}$ from its 1959 position. A maximum ice-surface velocity of $7.7 \mathrm{~m} \mathrm{~d}^{-1}$ (equivalent to $2.8 \mathrm{~km} \mathrm{a}^{-1}$ ) was measured over a period of 41 days in July-August 1959 (Hattersley-Smith, 1969). This surge may be continuing, or a further surge may have occurred, as the glacier surface is still highly crevassed in the 1999 Landsat 7 imagery, and the terminus is digitate and in a similar position to 1964 . Unfortunately no repeat Landsat 7 imagery is available for this location, so it has not been possible to determine present-day velocities. The active phase of this surge lasted a minimum of 5 years (between 1959 and 1964) and maybe as long as 50 years.

Several other glaciers close to Otto Glacier also appear to be surge-type, but have been classified as type 2 because their active phase has not been observed (Table 2; Fig. 1). The most notable are "East Hare Fiord" Glacier and Chapman Glacier, which were both mentioned by Hattersley-Smith (1969) as possible surge-type glaciers. These large glaciers display extensive folding and looping of moraines and ice foliation over their terminus areas in both the aerial photography and Landsat 7 imagery. Chapman Glacier also displays impeded surface drainage similar to that described by Sturm (1987) for surge-type glaciers in Alaska.

\section{Müller and Steacie Ice Caps}

Along the west coast of Axel Heiberg Island, three large glaciers appear to be surging at present, and all have advanced significantly since 1959/60. Müller (1969) discussed the surge of "Good Friday Bay" Glacier, and Ommanney (1969) mentioned that Iceberg Glacier (and tributary Finsterwalder Glacier) displayed evidence of a past surge. The surge of "Airdrop Glacier" has not previously been reported, however, and Iceberg Glacier has surged since Ommanney's (1969) report.

Müller (1969) reports that the lowermost $2 \mathrm{~km}$ of the $650 \mathrm{~km}^{2}$ Good Friday Bay Glacier became crevassed and advanced by $600 \mathrm{~m}$ between 1952 and 1959. From 1959 to 1964 the glacier terminus advanced a further $650 \mathrm{~m}$, with a large increase in the number of crevasses. Between 4 and $6 \mathrm{~km}$ up-glacier, surface lowering was suggested by a rim of ice some $10-15 \mathrm{~m}$ above the glacier surface. The maximum annual velocity over this period was $>250 \mathrm{~m} \mathrm{a}^{-1}$. The terminus advanced a further $600 \mathrm{~m}$ between 1964 and 1967, and by a further $200 \mathrm{~m}$ between August 1967 and April 1969. The 1992 Landsat 4 imagery indicates that the terminus had advanced by $\sim 7 \mathrm{~km}$ from its 1959 position, or approximately $\sim 5.5 \mathrm{~km}$ from its last recorded position in 1969. By 1999 the glacier had advanced by a further $\sim 100 \mathrm{~m}$ since 1992, infilling ice-marginal lakes in the process. It appears to still be surging in 1992 and 1999 as it is heavily crevassed across its terminus, with marked looping of surface moraines and ice foliation. Müller's (1969) measurements indicate that the active phase lasted for a minimum of 10 years, but the observations presented here suggest that the active phase may have lasted for 40 years or more. Without further imagery from the period 1969-92, it is not possible to ascertain whether the glacier went through a quiescent phase during this period.

Airdrop Glacier, one of the few currently surging glaciers in the QEI which terminates on land rather than in marine waters, has advanced by $\sim 4.5 \mathrm{~km}$ since $1959 / 60$ (Fig. 3). The glacier terminus was heavily crevassed in 1999 Landsat 7 imagery, and extensive surface folding and looping are apparent in both the 1999 imagery and the aerial photography. Unfortunately, this glacier is out of the range of the 1992 Landsat 4 imagery.

The tidewater terminus of Iceberg Glacier, to the south of Airdrop Glacier, advanced by $\sim 3.5 \mathrm{~km}$ between 1959/60 and 1992, and by a further $\sim 1.5 \mathrm{~km}$ between 1992 and 1999 (Fig. 4). This implies an active phase lasting at least 7 years, and probably much longer. The glacier surface is heavily crevassed with large looped moraines in both the 1992 and 1999 Landsat imagery, and some near-terminus surface features have been displaced by $\sim 4 \mathrm{~km}$ over this period. This equates to a mean 

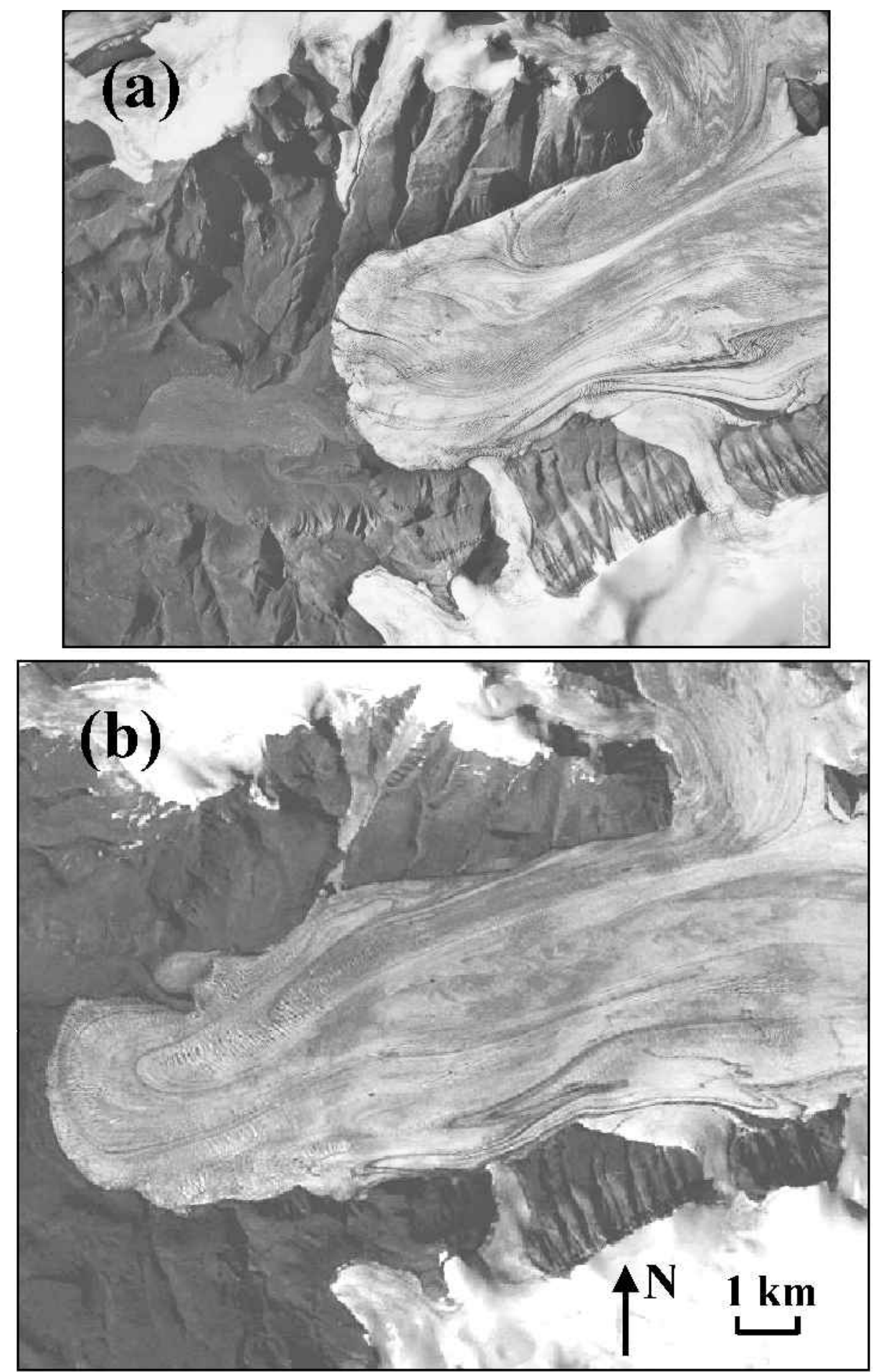

Fig. 3. The terminus of "Airdrop Glacier", western Müller Ice Cap $\left(79^{\circ} 50^{\prime} \mathcal{N}, 93^{\circ} 40^{\prime} \mathrm{W}\right)$ : (a) in 1959 aerial photography (C) A16755-052, 28 Fuly 1959); (b) in 1999 Landsat 7 imagery (path 060, row 002, 23 July 1999). Terminus has advanced $\sim 4.5 \mathrm{~km}$ between the two images.

annual velocity of approximately $575 \mathrm{ma}^{-1}$. In the 1959/60 aerial photography the glacier surface is largely uncrevassed, but very heavily potholed. The potholing is the most extensive observed on any glacier during this analysis, and it extended for a distance of at least $10 \mathrm{~km}$ up-glacier from the position of the terminus in 1959/60.

\section{Long duration of the active phase in the Canadian High Arctic and Svalbard}

In discussing the behaviour of Good Friday Bay Glacier, Müller (1969) pointed out that the long active phase (at least
10 years) inferred for this glacier implied that the dynamics of this glacier differed from those which are characteristic of "a classical surge". It is clear that many surge-type glaciers at lower latitudes have a much shorter active phase than Good Friday Bay glacier (Dowdeswell and others, 1991). However, the evidence presented above for surges lasting up to 50 years indicates that the behaviour of Good Friday Bay Glacier may not be unusual for surging glaciers in the Canadian Arctic archipelago. Müller (1969) concluded that long active phases might be a characteristic of subpolar surge-type glaciers, which contain cold ice close to the surface and sometimes at a thin margin, but may be at the pressure-melting point 

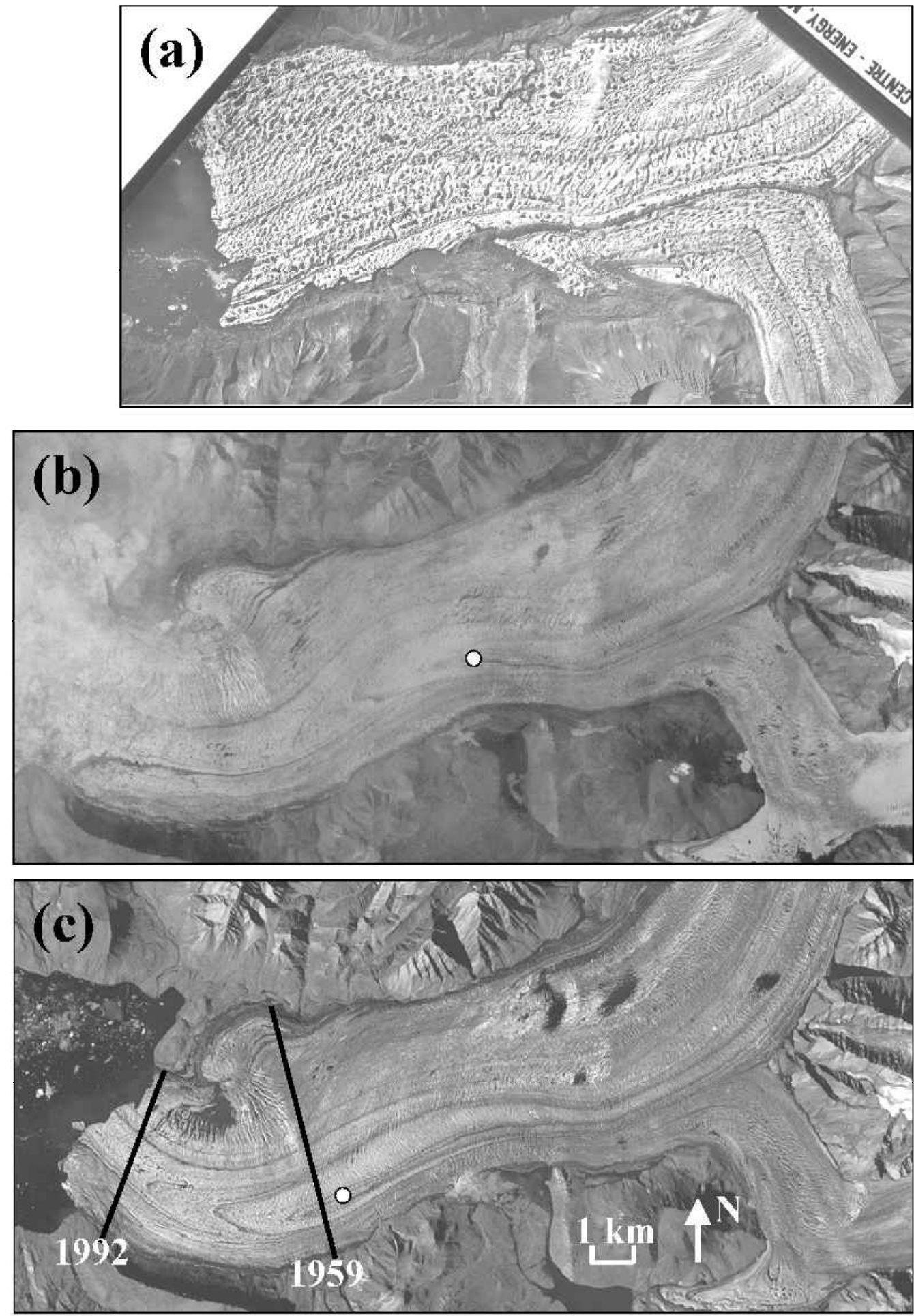

Fig. 4. The terminus of Iceberg Glacier, western Müller Ice Cap $\left(79^{\circ} 28^{\prime} \mathcal{N}, 92^{\circ} 15^{\prime} \mathrm{W}\right):$ (a) in 1959 aerial photography ((C) A16754-105, 7 July 1959); (b) in 1992 Landsat 4 imagery (slightly cloudy) (path 053, row 003, 18 July 1992), (c) in 1999 Landsat 7 imagery (path 053, row 003, 22 July 1999); lines mark approximate location of terminus from $(a)$ and $(b)$. White dot in (b) and (c) marks location of the same point in 1992 and 1999: displacement is $\sim 4 \mathrm{~km}$.

nearer to the bed. Glaciers with this thermal structure, sometimes referred to as polythermal glaciers, are also found in the Svalbard archipelago (Schytt, 1969; Dowdeswell and others, 1991). Observations from eight Svalbard glaciers show that they too have an active phase of long duration relative to surge-type glaciers in, for example, Iceland, the Pamirs and parts of Alaska (e.g. Dowdeswell and others, 1991; Murray and others, 1998). Observations by Jiskoot and others (2001), however, indicate that polythermal Sortebræ, East Greenland, has short active and quiescent phases similar to those observed on Alaskan surge glaciers.
In addition to possible thermal controls on surge behaviour, several workers have postulated a relationship between climate and the duration of the surge cycle. Eisen and others (2001) argued that the duration of the quiescent phase of the surge cycle at Variegated Glacier, Alaska, was determined by the time required to achieve a critical cumulative accumulation in the upper regions of the glacier. Thus the interval between surges was inversely related to the net balance in this region. Similarly, Dowdeswell and others (1995) argued that surging had become less common in Svalbard during the 20 th century because of a climatically induced shift to nega- 
tive mass balance, which had lengthened the quiescent phase of the surge cycle. There is some evidence that in high-accumulation regions where the duration of the surge cycle is relatively short, the active phase of the cycle is both short and intense (e.g. southeast Alaska; Lawson, 1997). In regions of lower accumulation, however, such as Svalbard and the Canadian Arctic, surges appear to be more long-lived and less intense (Müller, 1969; Dowdeswell and others, 1991). Discussion of the physical mechanisms that might explain this apparent linkage between mass balance and surging dynamics is, however, beyond the scope of this paper.

\section{GONGLUSIONS}

From an analysis of 1959/60 aerial photography and 1999/ 2000 Landsat 7 imagery, 51 potential surge-type polythermal glaciers have been identified in the Canadian High Arctic. Fifteen of these have been observed in the active phase. The data available suggest that the duration of the active phase of the surge cycle on glaciers in this region is relatively long, perhaps reaching as much as 50 years. The distribution of surging glaciers in the QEI appears to be non-random, as most of the surge-type glaciers identified are large tidewater valley glaciers draining to coastal areas with relatively high snowfall. Not all of the glaciers that occur in these areas are surge-type, however, so some other as yet unknown controls must also determine whether or not a glacier will surge.

Plans for future work include a more comprehensive analysis of the characteristics of surge basins (e.g. geology, slope, area, aspect and ice thickness). A search for imagery for the period 1960-99 is also planned, as this will permit improved estimates of the length of the active phase of the surge cycle in the Canadian Arctic.

\section{ACKNOWLEDGEMENTS}

This study was funded by U.K. Natural Environment Research Council grant NER/A/S/1998/00015 to Dowdeswell, and by grants from the Natural Sciences and Engineering Research Council, Canada, Environment Canada (MSCCRYSYS program) and the Canadian Space Agency (Climate and Cryosphere Initiative) to M.J. Sharp. We gratefully acknowledge C.S. L. Ommanney, R. Mackay, T. D. Prowse and the National Water Research Institute, Saskatoon, for providing us with access to the aerial photography. A. S. Dyke (Geological Survey of Canada) made available additional aerial photography of the Devon Ice Cap. G. Wolken, D. Burgess and K. Filbert assisted with the scanning. H. Jiskoot and M. Truffer provided helpful reviews of the manuscript. The aerial photographs in Figures 2a, 3a and 4a (C) 1959 Her Majesty the Queen in Right of Canada, reproduced from the collection of the National Air Photo Library with permission of Natural Resources Canada.

\section{REFERENGES}

Bindschadler, R., J. A. Dowdeswell, D. Hall and J.-G. Winther. 2001. Glaciological applications with Landsat-7 imagery: early assessments.
Remote Sensing Environ., 78(1-2), 163-179.

Copland, L. 2001. Polythermal glacier hydrology and ice flow dynamics. (Ph.D. thesis, University of Alberta.)

Dowdeswell, J. A. 1995. Glaciers in the High Arctic and recent environmental change. Philos. Trans. R. Soc. London, Ser. A, 352(1699), 321-334.

Dowdeswell, J. A. and M. Williams. 1997. Surge-type glaciers in the Russian High Arctic identified from digital satellite imagery. F. Glaciol., 43(145), 489-494.

Dowdeswell, J. A., G. S. Hamilton and J. O. Hagen. 1991. The duration of the active phase on surge-type glaciers: contrasts between Svalbard and other regions. F. Glaciol., 37(127), 388-400.

Dowdeswell, J. A., R. Hodgkins, A.-M. Nuttall, J. O. Hagen and G. S. Hamilton. 1995. Mass balance change as a control on the frequency and occurrence of glacier surges in Svalbard, Norwegian High Arctic. Geophys. Res. Lett., 22(21), 2909-2912.

Eisen, O., W. D. Harrison and C. F. Raymond. 2001. The surges of Variegated Glacier, Alaska, U.S.A., and their connection to climate and mass balance. F. Glaciol., 47(158), 351-358.

Hagen, J. O., O. Liestøl, E. Roland and T. Jørgensen. 1993. Glacier atlas of Svalbard and Jan Mayen. Nor. Polarinst. Medd. 129.

Hambrey, M. J. and J. A. Dowdeswell. 1994. Flow regime of the Lambert Glacier-Amery Ice Shelf system, Antarctica: structural evidence from Landsat imagery. Ann. Glaciol., 20, 401-406.

Hamilton, G. S. 1992. Investigations of surge-type glaciers in Svalbard. (Ph.D. thesis, University of Cambridge.)

Hattersley-Smith, G. 1964. Rapid advance of glacier in northern Ellesmere Island. Nature, 201 (4915), 176.

Hattersley-Smith, G. 1969. Recent observations on the surging Otto Glacier, Ellesmere Island. Can. F. Earth Sci., 6(4), Part 2, 883-889.

Iken, A. 1974. Velocity fluctuations of an Arctic valley glacier; a study of the White Glacier, Axel Heiberg Island, Canadian Arctic Archipelago. Montréal, Que., Mc Gill University. (Axel Heiberg Island Research Reports Glaciology 5.)

Jiskoot, H., T. Murray and P. Boyle. 2000. Controls on the distribution of surge-type glaciers in Svalbard. f. Glaciol., 46(154), 412-422.

Jiskoot, H., A. K. Pedersen and T. Murray. 2001. Multi-model photogrammetric analysis of the 1990s surge of Sortebræ, East Greenland. $\mathcal{F}$ Glaciol., 47(159), 677-687.

Koerner, R. M. 1989. Queen Elizabeth Islands glaciers. In Fulton, R. J., ed. Quaternary geology of Canada and Greenland. Geology of Canada 1. Chapter 6: Quaternary geology of the Queen Elizabeth Islands. Ottawa, Ont., Geological Survey of Canada; Boulder, CO, Geological Society of America, 464478. (The Geology of North America K-1.

Lawson, W. 1997. Spatial, temporal and kinematic characteristics of surges of Variegated Glacier, Alaska. Ann. Glaciol., 24, 95-101.

Meier, M. F. and A. Post. 1969. What are glacier surges? Can. 7. Earth Sci., 6(4), Part 2, 807-817.

Meier, M.F. and A. Post. 1987. Fast tidewater glaciers. 7. Geophys. Res., 92(B9), 9051-9058.

Müller, F. 1969. Was the Good Friday Bay glacier on Axel Heiberg Island surging? Can. 7. Earth Sci., 6(4), Part 2, 891-894.

Murray, T., J. A. Dowdeswell, D. J. Drewry and I. Frearson. 1998. Geometric evolution and ice dynamics during a surge of Bakaninbreen, Svalbard. 7. Glaciol., 44(147), 263-272. (Erratum: 45(150), 1999, p. 405.)

Ommanney, C. S. L. 1969. A study in glacier inventory: the ice masses of Axel Heiberg Island, Canadian Arctic Archipelago. Montréal, Que., McGill University. (Axel Heiberg Island Research Reports Glaciology 3.)

Ommanney, C. S. L. 1989. Glacier Atlas of Canada. Saskatoon, Sask., Scientific Information Division, National Hydrology Research Institute, Environment Canada. (Limited edition.

Post, A. 1969. Distribution of surging glaciers in western North America. $\mathcal{F}$ Glaciol., 8(53), 229-240.

Raymond, C. F. 1987. How do glaciers surge? A review. 7. Geophys. Res., 92(B9), 9121-9134

Scambos, T. A., M. J. Dutkiewicz, J. C. Wilson and R. A. Bindschadler. 1992. Application of image cross-correlation to the measurement of glacier velocity using satellite image data. Remote Sensing Environ., 42(3), 177-186.

Schytt, V. 1969. Some comments on glacier surges in eastern Svalbard. Can 7. Earth Sci., 6(4), Part 2, 867-873.

Sturm, M. 1987. Observations on the distribution and characteristics of potholes on surging glaciers. F. Geophys. Res., 92(B9), 9015-9022.

Williams, R. S., Jr, D. K. Hall and C. S. Benson. 1991. Analysis of glacier facies using satellite techniques. F. Glaciol., 37(125), 120-128. 